\title{
EFFECT OF MADHU-KSHARA SUTRA IN THE MANAGEMENT OF BHAGANDARA [FISTULA-IN-ANO]
}

\author{
Research Article
}

\section{Gopi krishna.B.J. ${ }^{*}$, Hemantha Kumar. $P^{2}$}

1. Associate Professor, 2. Professor \& HOD, Dept. of PG Studies in Shalya Tantra, SDMCA \& H, Hassan.

\begin{abstract}
Bhagandara (Fistula-in-ano) is a cumbursome disease which occurs in Anorectal region, it is second commonest disease after haemorroids. In this context, a comparative study was carried out to evaluate the efficacy of Madhu-Kshara Sutra in the management of Bhagandara. It consists of Madhu, Apamarga (Achyranthus Aspera) and Haridra (Curcuma longa). The subjects were treated with Madhu Kshara Sutra in study group and Apamarga Kshara Sutra in control group and the results were encouraging.
\end{abstract}

Keywords: Bhagandhara, Madhu Kshara Sutra, Apamarga, Haridra

\section{Introduction}

The word fistula is derived from a Latin word a reed, pipe or flute. It is an abnormal communication between two epithelial-lined surfaces. It usually results from an ano-rectal abscess, which burst spontaneously or opened inadequately. As the wound is located in anal region which is a storehouse for faeces so it is more prone for infection, thus takes long time to heal and the condition remains difficult to cure, various operative procedures often leads to complications like recurrences, scars and faecal incontinence.

In Ayurvedic classics, Bhagandara has been described as one of the Asta Mahagada means which is difficult to cure and it has similar signs and symptoms of Fistula-in-ano. The Kshara Sutra therapy was practiced and used since long time with great success and negligible

*Corresponding Author:

\section{Gopi krishna.B.J,}

Associate Professor,

Dept. of PG Studies in Shalya Tantra, SDMCA \& H, Hassan.

E-mail: drgopiboyapati@gmail.com recurrences. As the collection and preservation of Snuhi ksheera is difficult and time taking process, Madhu is easily available, preservable and equally effective. So Madhu was selected instead of Snuhi Ksheera in the preparation of Kshara Sutra, as Madhu is inherited with the properties of Vranashodana (Wound cleansing), Vranaropana (Woundhealing) and Lekhana (Scraping).

\section{Materials and method}

\section{Source of data}

A clinical study was planned on Madhu-Kshara Sutra and Apamarga Kshara Sutra in diagnosed cases of Fistula-in-ano from the OPD and IPD of Dept. of P.G.Studies in Shalyatantra, SDM College of Ayurveda and Hospital, Hassan, Karnataka and studies on 20 patients in each group.

\section{Inclusion criteria}

The cases were selected above age 12 years, both sexes, operative recurrences, different duration of signs and symptoms of Bhagandara (Fistula-in-ano). 


\section{Exclusion criteria}

1. Post operative incontinence of stool

2. Secondary fistula due to Crohn's disease, Tuberculosis, Ulcerative colitis and Carcinoma of Rectum.

\section{Preparation of Madhu-Kshara Sutra}

Table-1 pH of different drugs in Apamarga Kshara Sutra and MadhuKshara Sutra

\begin{tabular}{|l|l|l|}
\hline S.No. & Drugs & pH \\
\hline \multirow{1}{*}{1.} & $\begin{array}{l}\text { Apamarga Kshara } \\
\text { Sutra }\end{array}$ & 9.7 \\
\cline { 2 - 3 } & Snuhi & 5.6 \\
\cline { 2 - 3 } & Apamarga Kshara & 9.7 \\
\cline { 2 - 3 } & Haridra Kshara & $\mathbf{6 . 2}$ \\
\hline \multirow{6}{*}{$\begin{array}{l}\text { Madhu- } \\
\text { Sutra }\end{array}$} & $\mathbf{3 . 6}$ \\
\cline { 2 - 3 } & Madhu & 9.7 \\
\cline { 2 - 3 } & Apamarga & 6.2 \\
\cline { 2 - 3 } & Haridra & \\
\hline
\end{tabular}

Assessment criteria

Total No. of

days taken for

$\begin{aligned} & \text { 1. U.C.T. }= \frac{\text { cut through }}{\text { Initial length }} \\ & \text { of track in } \\ & \text { cms. }\end{aligned}$

2. Pain

3. Granulation Tissue

4. Discharge

5. Healing time after cut through

\section{Gradings :}

\section{2) Pain}

$\begin{array}{lll}\text { Grade } 0 & - & \text { No pain } \\ \text { Grade 1 } & - & \text { Mild } \\ \text { Grade 2 } & - & \text { Moderate } \\ \text { Grade 3 } & - & \text { Severe }\end{array}$

\section{3) Granulation Tissue}

$\begin{array}{lll}\text { Grade } 0 & - & \text { Healthy } \\ \text { Grade } 1 & - & \text { Moderate } \\ \text { Grade } 2 & - & \text { Hypergranulation } \\ \text { Grade } 3 & - & \text { Granulation absent }\end{array}$

4) Srava

Grade 0 - No discharge
Grade 1 - If Vrana wets $1 / 2 \times 1 / 2 \quad \mathrm{~cm}$ gauze piece (Mild)

Grade 2 - If Vrana wets 1 x $1 \mathrm{~cm}$ gauze piece (Moderate)

Grade 3 - If Vrana wets more than $1 \mathrm{~cm}$ (Severe)

\section{5) Healing time after cut through:}

Area of Group A and Group B of patients were compared with wound square $\mathrm{cm}$ area (compared) with the following formula.

Total no. of days of

U.H.T.=

$\frac{\text { wound healing }}{\text { Initial length } \mathrm{x}}=\ldots$.days $/ \mathrm{cm}$
Breadth $\mathrm{x}$
height.

6) Size of the wound:

Grade 0 - Healed

Grade 1 - $(0.5-1 \mathrm{~cm})$ wound within 0.5$1 \mathrm{~cm}$

Grade 2 - Wound within 1-2 cm

Grade 3 - Wound within 2-3cm

\section{Application of Madhu-Kshara Sutra}

The patient is kept in proper lithotomy position and perianal region was cleaned with antiseptic lotions and draped. Patient is reassured and gloved finger was gently introduced into the rectum. Then a probe was passed through the external opening of fistula. The tip of the probe was forwarded along the path of least resistance and was guided by the finger in rectum to reach into the lumen of anal canal through the internal opening and its tip was finally directed to come out of anal orifice. Then a suitable length of Plain surgical linen thread no. 20 was taken and threaded into the eye of probe. Thereafter the probe was pulled out through the anal orifice, to leave the thread behind in the fistulous track. The two ends of the thread were then tied together with a moderate tightness outside the anal canal. This procedure is called primary threading and 
on second day post-operative day the Madhu-Kshara Sutra application is done.

\section{Change of Madhu-Kshara Sutra}

All patients were instructed to take hot sitz bath before changing the thread. The Madhu-Kshara Sutra was changed at weekly interval. The thread is tied to the previously applied Madhu- Kshara Sutra in position towards outer end of the knot. Then an artery forceps is applied inner end to the same knot. Then the old thread is cut between the artery forceps and the knot. Pulling of the artery forceps along with the thread ultimately replaces the old thread by Madhu-Kshara Sutra. Then the two ends are ligated and bandaging was done. This procedure is done by Railroad technique. The same procedure is followed for successive changes of Madhu-Kshara Sutra at weekly interval.

\section{Follow-up}

All the patients were instructed to visit Ano-rectal clinic once in a week till the complete cut through of the fistulous tract.

\section{Observations and result}

The efficacy of Madhu-Kshara Sutra and Apamarga Kshara Sutra have been studied in 40 patients of Fistula-inano, divided into two groups, control group (Group A) - Apamarga Kshara
Sutra and treated group (Group B) Madhu-Kshara Sutra were applied.

All 40 patients of fistula-in-ano have been analysed for age, sex, occupation, habitat, nature of diet, Doshic Prakriti, type of Bhagandara, type of fistula-in-ano, position of the external openings, length of fistulous track and recurrent cases.

The length of the Madhu-Kshara Sutra was measured after each change and was noted in every case. After few days of therapy, this Sutra comes out with the knot intact. This stage is known as Cut Through. The Average Unit Cutting Time (U.C.T.) of treated group (Madhu-Kshara Sutra) was calculated and compared with control group (Apamarga Kshara Sutra). The analysis of average unit cutting time was noted in relation to age, length of track, and previous history of operation and different ' $\mathrm{O}$ ' clock position in each group.

The process of healing was started with the cutting of the track during the course of treatment. However, the small area was still remained to heal completely at the end of total cut through which took 1-2 weeks in treated groups in complete closure of the wound and where as 2-3 weeks was taken for healing completely in control group.

Table - 2 Average Unit cutting time Control and Treated Groups

\begin{tabular}{|l|c||}
\hline Group & Average unit cutting time in days/cm \\
\hline Control (Group A) & 8.67 \\
\hline Treated (Group B) & 9.35 \\
\hline \hline
\end{tabular}

Table - 3 Status showing the effect on U.C.T in therapy groups

\begin{tabular}{||l|c|c|c|c|c|c|l||}
\hline & Mean & S.D. & S.E. & t & df & 'p' Value & \multicolumn{1}{|c||}{ Inference } \\
\hline Group A & $8.67 \mathrm{~cm}$ & 1.085 & 0.243 & 35.60 & 19 & $<0.001$ & $\begin{array}{l}\text { Highly } \\
\text { significant }\end{array}$ \\
\hline Group B & $9.35 \mathrm{~cm}$ & 2.016 & 0.457 & 20.73 & 19 & $<0.001$ & $\begin{array}{l}\text { Highly } \\
\text { significant }\end{array}$ \\
\hline
\end{tabular}


Table - 4 Status showing the status of pain criteria in therapy groups

\begin{tabular}{|c|c|c|c|c|c|c|c|}
\hline \multirow{2}{*}{$\begin{array}{l}\text { Treat- } \\
\text { ment }\end{array}$} & \multicolumn{3}{|c|}{ Group A } & \multirow{2}{*}{$\begin{array}{l}\text { Treat- } \\
\text { ment }\end{array}$} & \multicolumn{3}{|c|}{ Group B } \\
\hline & Mean & $\begin{array}{c}\text { Mean } \\
\text { difference }\end{array}$ & $\%$ & & Mean & $\begin{array}{c}\text { Mean } \\
\text { difference }\end{array}$ & $\%$ \\
\hline $\mathrm{BT}$ & 1.95 & \multirow{2}{*}{0.4} & \multirow{2}{*}{20.50} & $\mathrm{BT}$ & 2.2 & \multirow{2}{*}{0.7} & \multirow{2}{*}{31.8} \\
\hline AT & 1.55 & & & $\mathrm{AT}$ & 1.5 & & \\
\hline
\end{tabular}

Table - 5 Status showing the effect of Granulation tissue in therapy groups

\begin{tabular}{||l|l|l|l|l|l|l|l||}
\hline & Mean & S.D. & \multicolumn{1}{|c|}{ S.E. } & t & df & 'p' Value & Inference \\
\hline Group A & -2.15 & 4.46 & 0.997 & -2.15 & 19 & $<0.02$ & Insignificant \\
\hline Group B & -2.00 & 3.80 & 0.85 & 2.35 & 19 & $<0.02$ & Significant \\
\hline \hline
\end{tabular}

Table - 6 Status showing the effect on Discharge in therapy groups

\begin{tabular}{|c|c|c|c|c|c|c|c|}
\hline \multirow{2}{*}{$\begin{array}{l}\text { Treat- } \\
\text { ment }\end{array}$} & \multicolumn{3}{|c|}{ Group A } & \multirow{2}{*}{$\begin{array}{l}\text { Treat- } \\
\text { ment }\end{array}$} & \multicolumn{3}{|c|}{ Group B } \\
\hline & Mean & $\begin{array}{c}\text { Mean } \\
\text { difference }\end{array}$ & $\%$ & & Mean & $\begin{array}{c}\text { Mean } \\
\text { difference }\end{array}$ & $\%$ \\
\hline BT & 2.05 & \multirow{2}{*}{1.65} & \multirow{2}{*}{$80 \%$} & BT & 1.95 & \multirow{2}{*}{1.6} & \multirow{2}{*}{$82 \%$} \\
\hline AT & 0.4 & & & AT & 0.35 & & \\
\hline
\end{tabular}

Table - 7 Status of wound healing in therapy groups after 7 days of cut through

\begin{tabular}{|c|c|c|c|c|}
\hline \multicolumn{2}{|c|}{ Therapy groups } & Mean & $\begin{array}{c}\text { Mean } \\
\text { difference }\end{array}$ & Percentage \\
\hline \multirow{2}{*}{ Group A } & BT & 1.25 & \multirow{2}{*}{0.15} & \multirow{2}{*}{$12 \%$} \\
\hline & 7 Days & 1.10 & & \\
\hline \multirow{2}{*}{ Group B } & BT & 1.20 & \multirow{2}{*}{0.40} & \multirow{2}{*}{$33 \%$} \\
\hline & 7 Days & 0.80 & & \\
\hline
\end{tabular}

Table 8 - Status of wound healing in therapy groups after 15 days of cut through

\begin{tabular}{|c|c|c|c|c|}
\hline \multicolumn{2}{|c|}{ Therapy groups } & Mean & Mean difference & Percentage \\
\hline \multirow{2}{*}{ Group A } & BT & 1.25 & \multirow{2}{*}{0.45} & \multirow{2}{*}{$36 \%$} \\
\hline & 15 Days & 0.80 & & \\
\hline \multirow{2}{*}{ Group B } & BT & 1.20 & \multirow{2}{*}{1.10} & \multirow{2}{*}{$91 \%$} \\
\hline & 15 Days & 0.10 & & \\
\hline
\end{tabular}

\section{Discussion}

Average unit cutting time in control group A is $8.67 \mathrm{~cm}$ and treated group $\mathrm{B}$ is $9.35 \mathrm{~cm}$. Pain felt by the patients at the time of changing thread and subsequent change of Madhu-Kshara Sutra was very less in compared to Apamarga Kshara Sutra, 31.8\% patients complained less degree of pain in Group B compared to $20.50 \%$ patients in Group A. Assessment of granulation tissue was proper in Group B compared with Control group A. Status of discharge in comparison with Group A and B, there was no much Mean difference in both the groups hence both are having significant on discharge. Status of wound healing in both groups after 7 days of cut through is $33 \%$ of cases in Group B as compared to $12 \%$ of cases in Group A. The total average U.C.T. was more in control group A than treated group B.

\section{Conclusion}

The aim of present study is to find out the efficacy and applicability of 
Madhu-Kshara Sutra in the management of Bhagandara. Based on the clinical statistical data, it may be concluded as follows:

- There was a marked reduction of symptoms like burning pain, irritation, inflammation, and local reaction in treated group as compared to control group.

- Availability and preservatory problems have been trespassed by the present method.

- It has minimized the problems of preparation and application of Kshara Sutra therapy.

- Wound healing after cut through was faster in treated group (1-2 weeks) as compared to (2-3 weeks) in control group.

- Madhu used to take 16 hours for drying in the Kshara Sutra cabinet.

- No recurrences of cases were reported during the six months of follow up study.

So, Madhu-Kshara Sutra can be considered as a better alternative in place of Apamarga Kshara Sutra because it has more acceptability, easily available, preservable, less burning pain while changing of the Kshara Sutra, irritation and better wound healing property after cut through.

\section{References}

1. Chunekar K.C. 1. BhavamishraBhavaprakash Nighantu. 10th ed.
Varanasi. Chaukhambha Bharati Academy; 1995

2. Pandit Kashinath Sharma and Dr.G.N. Chaturvedi. 2. Charaka, Vidyotini Hindi commentory Varanasi. Chaukhambha Sanskrit sansthan; 1975

3. Pandit Jagannath Sharma, Bajpai, Ganga Bishnu, Shri Krishna Das. Chakradutta: Chakrapanidutta. Bombay. Chakradatta Bombay ; 1959

4. Chaurasia, B.D. Human anatomy regional and applied. New Delhi, India. CBS publication; 1991

5. Deshpande P.J., Sharma K.R. Successful Non-operative treatment of High rectal fistula. Varanasi. ; 1976

6. Dhanwantari Veera- Management of High rectal fistula by Kshara Sutra, M.D. (Аy.), Thesis, I.M.S. B.H.U. (1983).

7. Goligher J.C. Surgery of the anus, rectum and colon. 5th ed. London.; 1984

8. Williams P.L. ELBS. Gray's Anatomy. 38th ed ; 1995

9. Hemantha Kumar, P.: Role of Aragvadhadi Sutra in the Management of Bhagandara, M.S.(Ayu.) thesis, I.M.S., B.H.U. (1996).

10. Vijayarakshita \& Srikanthadutta. Madhava Nidanam:Madhavakara with "Vidyotini" Hindi Commentary. 18th ed. Varanasi. Chaukhambha Sanskrit Sansthan; 1989

11. Arunadatta, Hemadri. Vagbhata: Astanga Hridaya .with commentaries of 'Sarvangasundari. Varanasi. Krishnadas Academy; 1982. 